\title{
Indigenous Cultural Studies: Intersections Between Cultural Studies and Indigenous Studies
}

\section{Eve Vincent, Timothy Neale and Crystal McKinnon}

History, Power, Text collects together selected contributions on Indigenous themes published between 1996 and 2013 in the journal first known as UTS Review and now known as Cultural Studies Review. Since the journal's inception, successive editors have sought to open up a space for new kinds of politics, new styles of writing and new modes of interdisciplinary engagement. Like the journal it draws its material from, this collection has been conceived and assembled as an exercise in institution building beyond 'the Institution'. We call this institution, tentatively, 'Indigenous cultural studies' and see it as a disciplinary space that is built iteratively through events, single articles and books. We do not seek to prescribe or delimit this project but rather to give it density and energise those working in the overlapping fields represented here.

Indigenous cultural studies is our name for the intersection of cultural studies and Indigenous studies, a crossing often expressed as, but certainly not limited to, cultural studies with Indigenous topics, Indigenous scholars doing cultural studies or Indigenous studies of culture and everyday life. Just as John Hartley describes cultural studies as 'a crossroads or bazaar for the exchange of ideas from many directions', Indigenous cultural studies is the exchange-in the sense of both a transactional site and a transactional actthat occurs at the meeting point of these diverse undertakings. It is the site where the scholars republished here might form 
and defend inquiries, and modes of inquiry, and where their 'discipline' is not primarily grounded in method or topic, but in their mutual textual presence. This collection seeks to (re) build this particular bazaar by identifying the conditions and fact of its existence and by revisiting some of the ideas and directions that have shaped the meeting of cultural studies and Indigenous studies.

The authors in this collection come from very different disciplinary backgrounds, yet they all found a home for their work in a cultural studies journal. Now, as we bring them into a new relationship with each other, they find themselves situated in a different institutional context again. While the journal itself was conceived by academics from within the discipline of cultural studies, few, if any, of the authors published here commonly label themselves as cultural studies scholars. They include individuals working in philosophy, cultural studies, literary studies, anthropology, education and law departments; people who were undergraduate students in the Humanities and postgraduate students in the Sciences; people who have always worked in the academy and people who have moved outside the academy. But despite all this disparity in disciplinary and institutional settings, these authors chose to place themselves in the same publishing context not once but twice. Why?

Some insight towards answering this question may be found in the history of the journal, its ethos and its inception. UTS Review was founded only a few years after the High Court's 1992 Mabo decision, which recognised the fact of Indigenous ownership of the Australian continent in 1788, and the 1993 drafting of the Native Title Act, which provided a mechanism for recognising Indigenous groups' rights in traditional lands. Suffice to say, the mid-1990s were characterised by an intense level of public conversations and contestations about the colonial past, the legacy of this past and the potential for Mabo to act as a rupture between the colonial past and an imagined postcolonial future in which Indigenous and non-Indigenous Australia might be 'reconciled' and past injustices rectified. From the outset, UTS Review both played a part in these urgent conversations and offered critical perspectives on the terms of this public engagement with Indigenous 
issues. Within the pages of this journal and in the composition of its editorial board-including, at its outset, Ian Anderson, Jackie Huggins, Mudrooroo and Phillip Morrissey - we see evidence of a commitment to politically and ethically engaged scholarship and to experimentation, the legacy of which might impel others.

In assembling a collection that republishes work from this journal, then, our aims are twofold. The first is to sketch a genealogy of the work contributing to the development of Indigenous cultural studies that has been undertaken within the journal. The second is to highlight the significance of an interdisciplinary space - a meeting point - that this journal played such a large part in instantiating. Here, for example, historians probed the limits of archival research methods, plumbing the silences in the archives and interweaving contemporary voices and perspectives on the past. Anthropologists, to cite another example, turned their attention to new subjects and new critiques, embracing, perhaps, the opportunity to publish work within a disciplinary frame not overshadowed by the colonial legacy in the same way that anthropology had been over this period. The journal certainly opened up a space for novel intersections, and in presenting this selection of essays from it we hope also to bring these pieces into an exciting new relationship with each other.

Graeme Turner recently asked 'what's become of cultural studies?' As we surveyed the work published over nearly two decades in this journal, a crucial question for us emerged: 'What's become of cultural studies' engagement with indigeneity?' Just as Turner's pressing concern is the global discipline's attachment to 'its original political, ethical and pedagogical mission', cultural studies in Australia retains an uncertain link to one of its earliest and most important areas of inquiry. ${ }^{2}$ Historically, the discipline has been defined by attempts to open up the Humanities and Social Sciences to neglected histories and modes of thinking - often, admittedly, while indicting them - a task that has been conditioned in specific ways within settler colonial and 'postcolonial' nations such as Australia. Cultural studies scholars have been critical of the production of nationalist and naturalising discourses within such a context, ineluctably leading these scholars 
back to colonial dispossession and Indigenous histories and knowledges.

But has this interdisciplinary intellectual project faltered? Have its energies receded or been redistributed into other concerns? Alternatively, we might ask, does the work of cultural studies scholars in this space exhibit the tendencies that Turner parodies and holds responsible for the wider discipline's lassitude: 'clever readings' of contemporary popular culture, celebrations of new technologies and everyday 'resistance', applications of a 'fashionable theorist' to obscure texts, and so on? ${ }^{3}$ We would suggest that the situation is not one of regulated predictability and esotericism, as outlined by Turner, but of disparate commitment. That is, research and teaching in the field of Indigenous cultural studies remains reflexive, critical and political, but there is less of it and it is less dense and less coordinated. Moments and spaces of condensation exist - the Blacklines collection edited by Michele Grossman in 2003 and the 'Critical Indigenous Studies' issue of Cultural Studies Review edited by Moreton-Robinson in 2009, for instance - although they appear as events more than institutions.

Yet, over the same period that we detect fragmentation within cultural studies, Indigenous studies programs have emerged and solidified their place within Australian higher education institutions. Some of the earliest Indigenous studies programs were centred on critically examining contemporary Indigenous politics and histories, one such early example being Monash University's Centre for Research into Aboriginal Affairs, established by Colin Tatz in $1964 .{ }^{4}$ As Zane Ma Rhea and Lynette Russell point out, the subsequent rise of Indigenous studies programs coincided with the professionalisation of degrees in education, nursing, social work, policing, law and health. The 1970 s and 1980s, in particular, saw a new emphasis on training programs for Aboriginal workers in education. ${ }^{5}$ Currently, many universities mandate some Indigenous studies content for all students in these fields, which is of the utmost importance, given that graduates are likely to be involved in providing services to Indigenous people and communities. ${ }^{6}$ 
The professionalisation of Indigenous studies was complemented in the 1990 os by an emerging - or perhaps re-emerging - scholarly focus on Indigeneity. Though courses with an Indigenous focus were increasingly being taught within traditional Humanities disciplines, they were often being led by non-Indigenous academics. As Heidi Norman documents, Indigenous-themed courses, where Aboriginal scholars assumed 'the role of teaching about "us", often had to be wrestled from anthropologists. ${ }^{7}$ Such programs, Dudgeon and Fielder suggest, became important Indigenous-directed spaces for Indigenous people to engage in and critique 'discourses about themselves' and privilege Indigenous knowledges. ${ }^{8}$ By 1999, Linda Tuhiwai Smith wrote about a 'burgeoning international community of Indigenous scholars and researchers' who were 'talking more widely about Indigenous research, Indigenous research protocols and Indigenous methodologies'. ${ }^{9}$ As in cultural studies, the ultimate political potential of critiquing knowledges and epistemologies remains an open question. What is the relation between denaturalising dominant conceptual frameworks and political action? There are other crossovers with cultural studies that can be stated more positively-shared texts, shared methods, shared scholars, shared spaces - though we would emphasise their common ambivalences. What Indigenous studies is, its disciplinary frameworks, its knowledge(s), its limitations and its possibilities continue to be an important and ongoing debate, currently taken up, for the most part, by Indigenous academics both here in Australia and globally. ${ }^{10}$

Throughout this collection, certain concerns are raised and return. Among them are Indigenous peoples' demands for recognition; the exercise of sovereignty, both by the settler state and by Indigenous peoples; and the meaning of land or country. Certain moments are also the source of response and reflection for many authors, particularly the 1992 Mabo decision, which seemingly carved out a space for Indigenous sovereignty, and the 2007 Northern Territory Emergency Response ('the Intervention'), when, for many, Indigenous human rights, let alone sovereign rights, were denied and the land was stolen once again. Collectively, these attachments not only demonstrate one way in which works by these 
scholars have been orientated towards issues affecting the lives and livelihoods of Indigenous people, but also how they are understood as significant for Indigenous and non-Indigenous Australians alike. It is through such scholarship that connections are forged between the page and real life, and between both Indigenous and non-Indigenous academics and Indigenous communities. While, as Lester-Irabinna Rigney informs us, 'Indigenous researchers are more accountable, not only to their institutions, but also to their communities', ${ }^{11}$ it is increasingly more commonplace for these communities to both regulate and collaborate in research by non-Indigenous scholars also. Today, the disciplines of cultural studies and Indigenous studies are linked in many ways by common attempts to create tangible connections between academia, society and communities. We argue that these authors' works, situated at the intersection of Indigenous cultural studies, are seeking to create change, transcending borders within the community, and between people and institutions.

\section{Articulated power}

Unsurprisingly, the most frequent theoretical touchstone across this book is French historian Michel Foucault. The power/knowledge nexus so brilliantly identified by Foucault has been an indispensible critical tool to scholars concerned with the 'critique of colonial knowing'. ${ }^{12}$ Everywhere in this collection we see the analysis of colonial and contemporary discourses about indigeneity. Aileen Moreton-Robison, for instance, utilises Foucault's genealogy of rights to resituate the settler-Indigenous relation as one dominated by patriarchal white sovereignty exercising its power through racialised rights. ${ }^{13}$ Many authors also turn their attention to what Foucault called 'subjugated knowledges', ${ }^{14}$ retrieved here through oral history, textual analysis and ethnography. These include the extensive body of knowledge held by Indigenous people about whitefellas' habits and cultural mores, evidenced on the streets of a country town in anthropologist Gillian Cowlishaw's work, for example, through subversive performances, mockery and delicious irony.

However, it is the depth of the influence of the late Stuart Hall that we find especially striking. Hall's death in early 2014 
has occasioned much reflection on his intellectual project, and we have identified three specific aspects of his work (and his influential reading of Antonio Gramsci) that have shaped the engagement of cultural studies scholars with indigeneity. The first is a dialectical account of power, utilised by (but not unique to) Hall, ${ }^{15}$ which remains attentive to relationships of domination and subordination; relationships embodied and reified through institutions, languages, spatial practices and so on; and the reproduction of power relations through processes of incorporation and resistance. There is no power without resistance, a point that of course Foucault also acknowledged, even as he dedicated himself to the analysis and elaboration of disciplinary and bio-power rather than resistance to it. For Gramsci, the conditions of domination also generate conditions of potential affordance; new interventions by power elicit new occlusions from power.

The second, related, trace of Hall's influence is in scholars' refusal to identify determinate social structures. His 'articulation approach' accepts the determining effects of power relations while categorically denying the 'belongingness' or necessary quality of any element within a given situation. As Hall argues, a theory of 'articulation' is aimed at:

understanding how ideological elements come, under certain conditions, to cohere together within a discourse, and ... how they do or do not become articulated, at specific conjunctures, to certain political subjects. ${ }^{16}$

This is best exemplified in Hall's account, after Gramsci, of the state as a complex intractably engaged in often-enigmatic struggles on multiple fronts with multiple publics. Penny van Toorn's contribution draws on the scholarship of the Subaltern Studies group to carefully consider the limits of Gramsci's distinction between civil society and the state, the former eliciting consent and conformity, the latter ensuring discipline 'through direct rule and physical coercion'. ${ }^{17}$ Acknowledging Ranajit Guha's rejection of this model as Eurocentric-Guha characterised the British colonial state in India as 'dominance without hegemony' - van Toorn argues that coercion outweighed hegemony on many Aboriginal 
reserves and missions. ${ }^{18}$ The archival records of this period, the 'public transcripts of powerless people', are read as discursive performances of subordination, necessary to the survival of a coercive regime. ${ }^{19}$ But van Toorn also reads the 'hidden transcripts' of the Lake Condah community, revealing the things that could not be safely said publicly and which struggle for emergence in the state's archive of itself.

Contradictory currents underpinned the state-based late nineteenth-century protectionist system that created these missions and reserves. The confident colonial teleology, shared by evolutionary anthropology - which assumed Indigenous decline and mutual protection through segregation - met anxious, moralising discourses of degradation and proliferation. For Tony Birch, the Victorian Aborigines Protection Act 1886 remains central to understanding, first, the alienation of Victorian Kooris from their country, and second, contemporary struggles for Koori identity which take place on the terrain of the past. Significantly, Birch dismisses any appeal to theories of 'agency', emphasising the severity and 'ruthless bureaucratic efficiency' of coercive colonial state. ${ }^{20}$ For others the act of enduring has come to represent the Indigenous capacity to elude state objectives over time. Tellingly, Irene Watson joins surviving with resisting in the reference to herself as a 'resisting-survivor'. ${ }^{21}$ Further, the archived past left behind by colonial bureaucratic regimes has been used by Birch in the present as a creative resource as well as being more broadly used as a source of contemporary Koori identities. $^{22}$

Finally, the influential Gramscian account of 'ideology' is in evidence throughout the collection. Ideology, Hall explains, is not a set of directives from above. It is a fragmentary and 'necessarily and inevitably' contradictory formation of discourses, working to both elicit our consent and invite (contained) forms of resistance. ${ }^{23}$ Gramsci's non-reductive approach to questions of race and class, as well as his insights about the constitution of 'subjects of ideology' are, Hall insists, vitally useful to theorists of racialised subjectivities, the subaltern, colonialism and racisms (which must be discussed in their historical specificity). ${ }^{24}$ The pre-given unified ideological subject is undone. Instead, we are invited to recognise: 
the 'plurality' of selves or identities of which the so-called 'subject' of thought and ideas is composed. [Gramsci] argues that this multi-faceted nature of consciousness is not an individual but a collective phenomenon, a consequence of the relationship between the 'self' and the ideological discourses which compose the cultural terrain of a society. ${ }^{25}$

These selves are of course composed in part by colonial thought. Hall's work helps us grasp the ways ethnic and racial difference can be 'constructed', and we would add experienced, as a set of antagonisms within a class. For Hall, ideology is not the intervention of power but rather 'the terrain on which [people] move, acquire consciousness of their position, struggle, etc'. ${ }^{26}$ The spatial metaphor of ideology as a cultural 'terrain' has particular resonance in Australia, where the fiction that the continent was terra nullius ('land belonging to no one', or no one's terrain) before European colonisation legitimated the British Crown's assertion of sovereignty in 1788. Although this legal falsehood was overturned by the 1992 Mabo decision, its ideological effects have proved resilient. As Indigenous scholars such Moreton-Robinson have argued, the nation's legitimacy and territorial unity are the keystones of Australian ideology, premised on the displacement of Indigenous societies and their knowledges, languages, economies, geographies and sovereignty within the national culture. ${ }^{27}$ In the Australian settler colony, the question of the 'post' in 'postcolonial' remains particularly vexed. There is, as Jane M. Jacobs suggests, a 'fantastic optimism' to the word, ${ }^{28}$ containing within it a certain anticipation that is, at the same time, a certain forgetting of the present perpetuation of colonial relations. ${ }^{29}$ For Deborah Bird Rose, the end goal must be negotiated, dialogical forms of 'decolonisation' worked out between peoples 'whose lives have become entangled in the violence of colonisation'.$^{30}$ In this collection, attention is more often weighted towards scrutinising the 'originary violence' of terra nullius and to thinking through its consequences, symptoms and genealogies, remaining attentive to the strategies of recognition and denial used to contain indigeneity's political potentials. 
Yet, as is evident in this collection, Indigenous difference is articulated within the ideological 'terrain' of the state. At the same time that forms of social disciplining may devalue everyday Indigenous social practices as archaic and/or anachronistic, 'cultural difference' may be essentialised or fetishised through official recognition and market activity. It is too simple to state that the ideology of the nation state only involves the absolute negation of indigeneity, as there are evidently moments when difference is desired or demanded. Bird Rose and Heather Goodall each note how idealisations are integral to both the avowal and the denial of present day Indigenous realities. This is the 'cunning of recognition' identified elsewhere by Elizabeth Povinelli: difference is valued by the liberal multicultural state until the point it recoils from 'radical alterity' or too much difference, revealing its intolerance. ${ }^{31}$ Using Hall and Gramsci, we can see that ideology is not to be found in one strategy but in the attempt to maintain a monopoly on the right to define indigeneity. ${ }^{32}$ 'Who we are', writes Irene Watson, 'is often navigated from a violent space within which Aboriginality is measured for its degree of authenticity, and where those who do the measuring are ignorant or deniers of the history of colonialism.' ${ }^{3}$

Scholars writing in contexts outside Australia - such as Chris Andersen, Devleena Ghosh and Brendan Hokowhitu, among others - have been equally attentive to the movement of indigeneity between desire and denial. Ben Dibley considers this problem in light of the official biculturalism of Te Papa Tongarewa, the national museum of Aotearoa New Zealand, where Maori are simultaneously celebrated, monetised and depoliticised by their co-option into a narrative of national commensalism. What appeared to many as a progressive reconciliation of two peoples in a national institution - 'Te Papa' often being translated as 'Our Place' - is also a rearticulation of the value and meaning of Indigenous difference in a neoliberal register, positioned now as a commodity whose forms are reassessed as either economically valuable, and therefore worthy of reproduction, or not. ${ }^{34}$ We should be careful, however, not to overemphasise the extent to which 'authentic' cultural difference is celebrated by the state and others. For Irene Watson, 'equality' is but a masquerade 
and 'annihilation' remains the state's key modality. ${ }^{35}$ There is no shortage of sociological or anthropological evidence to demonstrate the interpersonal and institutional discrimination that continues to be experienced by Indigenous people in Australia and other settler-colonial states. In Cowlishaw's work, the Murri residents of the shared social domain of a country town are explicitly introduced from infancy to the fact of being an 'Aborigine', a subjected state of being. ${ }^{36}$ And Lisa Slater's work in remote Indigenous communities indicates there is little sense that the adults and children at Indigenous cultural festivals feel that they or their practices are valued or prized by 'the mainstream' of the non-Indigenous nation. ${ }^{37}$

The case of pathologised indigeneity requiring remediation is different again..$^{38}$ The points of articulation between state power, embodied difference and liberal desires are carefully plotted by Tess Lea. Her analysis of the institutionalised creation and circulation of health 'facts' about Indigenous people illustrates the potential to denaturalise techniques of power and knowledge within this critical framework. Under the precepts of liberal governmentality, a social phenomenon must be made legible before it can be made the object of technical intervention (or 'policy'), and, just so, these 'facts' are produced under the sign of social justice to remediate Indigenous social disadvantage. What is compelling about Lea's analysis is that it shows not only that the creation of 'facts' are themselves a depoliticised intercession - a politics that appears as neutral and technical-but that these 'facts' have a life of their own within the order of settler governance. Practically, the 'Indigenous governance machine', as Emma Kowal calls it, is occupied by the task of reproducing its specific textual forms. ${ }^{39}$ Similarly, Virginia Watson argues that social 'crises' come to be naturalised as pre-existing their discovery through being textualised. In the case of the Howard government's Intervention in 2007, this means being narrated and then mediatised. In the Intervention, Irene Watson sees a frightening instance of ideological and historical convergence, a moment, recognisable within a historical genealogy of state power, in which the state retains a 'vested interest in maintaining the founding order of things'. ${ }^{40}$ 


\section{'Not a word' of history}

In this collection, the questions of power we outline above are thickly entangled with questions of authority and method, eliciting experiments with the possibilities of writing, speech and voice. Many contributions exhibit an implicit or explicit understanding of both the institutional power of the academy, and recognition that the histories and knowledges at work are always potentially dominated or dominating, before the fact. Repeatedly, these contributors respond by drawing attention to their encounters with spaces and gaps, the limits and possibilities of the archives, the centrality of forgetting, and the potentially productive force of that which is not known but which 'might be something'. Doubt, reflexivity and dialogical exchange feature as these writers speak without assurance; in the 'postcolonial' moment it is assurance that is rendered 'strange'. ${ }^{41}$

As is well known, since the early 1980 os the singular story of the 'settled' nation has been unsettled by Indigenous and non-Indigenous revisionist historians contesting the colonial and national historiography. Significantly, Henry Reynolds, a foremost non-Indigenous historian, published The Other Side of the Frontier in 1981 as an attempt to corroborate the oral histories of frontier violence that had long circulated in Queensland. Since these initial intercessions, Aboriginal experiences of and perspectives on invasion, violence and dispossession, previously excluded from a national narrative centred on modernity and progress, have been forcefully asserted and in some cases incorporated into public discourses, narratives and institutions. ${ }^{42}$ Nonetheless, while many contributors note Mabo's importance, for example, and the broader fact of these public contestations in the 1980 os and 1990s, the focus here is firmly on these issues' corollary. In short, disruptions of settler certainties about the events of the colonial past have also involved disrupting any certainty surrounding how it is we come to know about that past.

The figure of Captain Cook provides a concrete example of the new possibilities for history within cultural studies; he is clearly 'good to think with', to use Levi-Strauss' felicitous phrase. ${ }^{43}$ Across Aboriginal Australia, histories of Cook tell another story of invasion and the coming of a second law and 
social order. These histories are a 'vehicle for analysis', says Rose, as in the former Kimberley stockman, 'master storyteller and political analyst' Hobbles Danayarri's compelling narratives about Cook, which Rose reads as commentaries on the moral content of the colonial encounter. ${ }^{44}$ Taking their cue from Danayarri, key cultural studies scholars in Australia such as Stephen Muecke, Chris Healy and Katrina Schlunke have 'experimented' with Cook as they engage in new forms of history-making within a field of disruption and openings. Rather than 'making space' for Indigenous 'voices' that might undergo translation into a transcipt for incorporation, Muecke makes full use of recordings in Aboriginal English, relishing their distinctive cadence and narrative style. A textual and textualised difference is brought out onto the page. Equally, the two interviews in this collection work in a multivocal register: separate, disembodied voices meet, traffic in ideas, and take obvious pleasure in their talking, but the gaps and frictions of conversation are preserved within the text. Anne Brewster's interview with author Kim Scott and Christine Nicholls' talk with painter Kathleen Petyarre both probe the potential and limits of exchange through and about 'the coloniser's language'. ${ }^{45}$ Petyarre ends by signalling that the conversation cannot go on without transgressing the border between sayable and secret realms. She is unable to say more. 'Not a word.' ${ }^{46}$

Sonia Smallacombe's contribution also deals with the question of voice through her interrogation of the epistemology of the tape recorder. In an essay that foreshadows the 1997 Bringing Them Home report on Aboriginal children 'wrenched from their families' and placed in forms of state administration, ${ }^{47}$ Smallacombe draws attention to the narrative conventions and processes of selection associated with researchers' attempts to elicit 'oral histories'. Oral histories are associated with the exciting challenges posed to historical master narratives as feminist, working-class and other 'histories from below' gained ground in the 1960 s and 1970 s, ${ }^{48}$ but they are also in themselves a kind of historical artefact which came to encode new norms. The opening question, for example, routinely becomes a 'beginning'. Trauma, as the anthropologist Michael Jackson states, interrupts the capacity to tell stories, 
but oral historians need whole narratives with beginnings and endings just as humans need stories to live by. ${ }^{49}$ Arguing that histories are 'cultural forms of knowledge',50 Smallacombe sets out to work against Western linear narratives, collecting oral histories of the trauma of removal that ascribe seasons and kin relations a more central mnemonic function than events. Disrupting disciplinary conventions demands self-reflexivity about the forms of history-making that are everywhere naturalised. As the authors in this collection aver, the archive has its own history and cannot be mistaken for a full account.

We note that both Irene Watson and Smallacombe are Indigenous scholars who acknowledge their 'outsiders' status as they research and write about specific Indigenous realities. This is a de-essentialising move, these scholars making clear that they do not automatically access transcendental knowledge about what it means to be Aboriginal nor do they position themselves as having a secure authority to speak about all things Aboriginal. As Rigney notes, 'there is no cultural homogeneity among Indigenous Australians ... There is no automatic or natural rapport between Indigenous Australians. ${ }^{{ }^{1}}$ Further, their reflections break down not just the overlay of insider/outsider onto the Indigenous/settler distinction but also break down the researching non-Indigenous subject/ Indigenous object distinction that continues to structure many anthropological inquiries. By contrast, Bronwyn Fredericks suggests that as 'another Aboriginal woman' she was in a position to design research questions responsive to Aboriginal women's interests, and on this basis was entrusted with Aboriginal women's stories about their lived marginalisation..$^{2}$ As Rigney suggests, for many it is 'politically more appropriate that Indigenous Australians speak through Indigenous researchers'.53

Rebe Taylor also takes the reader into another kind of possibility for the researcher-researched dynamic. Attentive to the complex power relations at play, Taylor addresses the exchange of information, theories, questions and feelings between herself and the Indigenous descendants of sealers and Tasmanian Aboriginal women taken far from their homes to Kangaroo Island, South Australia.54 Wendy Brady says she is tired of the kinds of historical works written by 
well-meaning scholars who do not make a connection with Aboriginal people for whom the experiences of the past are not 'historical' but everyday and lived;55 on Kangaroo Island this problematic separation is sutured.

Taylor's contribution concludes with a careful discussion of the ways that which is not known - the fact of being 'deprived' of one's history - is both something missing and also something experienced. 'Not knowing their history was in fact their inheritance', and a sense of loss is incorporated into a sense of belonging. ${ }^{56}$ That which is not known or not declared is also central to Alison Ravenscroft's re-readings of Roberta Sykes's autobiographical trilogy. Ravenscroft notes that the reader might seek from these works 'full and certain knowledge' about Sykes's parentage, ${ }^{57}$ hopes that the texts themselves refuse to fulfil. While Sykes's mother maintains her secrecy over the identity of Sykes's biological father, Ravenscroft employs a reading practice that probes Sykes's mother's secrecy about her own racial identity. Ravenscroft renders Sykes's mother's whiteness ambiguous, unfixed and uncertain. The indeterminancy of these hierarchised racial categories is made clear by Sykes's mother's efforts to accomplish the 'making-white' of her daughters, an objective which is only ever provisionally realised, and which is brutally undone when Sykes is raped..$^{8}$ The work of Taylor and Ravenscroft, like that of many others in this collection, make clear how cultural studies scholars have persistently remained committed to mapping the ambiguities and effects of historical production rather than producing a newer synthesised historical 'truth'.

\section{Counter-narratives and counter-texts}

The above suggests that, for these scholars, histories and life stories are not only inseparable from the social and linguistic context of their emergence, but also from their specific textual expressions. In the Black Soil country of northwest New South Wales and southwest Queensland, Goodall identifies how narratives of 'modernity' and 'tradition' are solidified through textual production and reproduction. For non-Indigenous pastoralists, newsletters, oral histories of specific plants or the collected reflections of 'pioneer' families are all expressions 
and evidence of belonging, reproofs against the incursion of large-scale irrigators. Alternatively, Goodall notes, Indigenous peoples' belonging has been irrevocably conditioned by the emphasis on both 'tradition' and the colonial archive as sources of legal legitimacy after Mabo. This emphasis, Goodall and others note, has been amplified by the finding in 1998 that some implacable 'tide of history' might 'wash away' these sources of recognition. ${ }^{59}$ In Eve Vincent's contribution, counter-narratives that assert Indigenous belonging are produced and reproduced through oral, textual and spatial practices. The senior Aboriginal women of Kupa Piti (Coober Pedy) travelled the country between 1998 and 2004, in protest against the decision to store nuclear waste in the traditional country. Like Danayarri's use of the Cook narratives, the Kungka Tjuta strategically recalled their past experiences of the British nuclear testing program in the 1950 s as a means of analysing and also affecting the present. ${ }^{60}$

While Vincent's piece argues that the colonial imagination produces the desert as an empty, blank dead space, in Fredericks's contribution the spatial organisation of institutional sites are dissected from the perspective of Aboriginal women. The women she interviewed about their experiences of Queensland health services confirm the interrelated nature of 'who women are' and 'where women are'. ${ }^{61}$ Fredericks's fine-grained analysis of Aboriginal women's experiences reveals the way relations of domination and subordination have a spatialised aspect. In a stark example, the Indigenous Health Program was for a time located at the back of a building, requiring an Indigenous patient to first gain permission from a non-Indigenous administrator before being directed to the service. The symbolic configuration of the relationship between the public entrance, the mediating role of the reception desk and the Indigenous service's location mirrored the colonial order, reinforcing the women's sense of alienation from a site that was, ironically, designed to be 'inclusive' of a range of specific, differentiated health services.

The theme of shame recurs across this collection. While many anthropologists discuss the social role of the intense shame that is part of many Indigenous lifeworlds, ${ }^{62}$ in this volume shame is produced through the colonial relation. 
Slater comments, for instance, that remote Indigenous youth feel shame 'in the mainstream'. ${ }^{63}$ Robyn Ferrell's essay is dedicated to exploring the white body as the site and source of postcolonial shame. Recalling the Western Australian country town of Pinjarra, circa 1970, Ferrell explains how white farmers' children warned each other not to drink from the taps Aboriginal children had touched with their mouths, a parallel to the sensed contamination of the social body by the reserve on the edge of 'town'. Contact between excluded black bodies and the town's white bodies contaminated both realms, and 'our common shame' demoralised both. ${ }^{64}$ Ferrell powerfully joins the shame of the self-conscious adolescent girl under the public gaze - 'eating the gluey pie from the bakery even though "they made you fat" and it was "unladylike" to eat in the street' - with the politicised shame of the postcolonial subject, who becomes aware she grew up upstream from a massacre site. ${ }^{65}$

Ferrell's work contrasts with Biddle's arresting reading of Central Desert women's bodies as canvas texts and canvasses as country. Where Ferrell's awkward body is under the gaze, Biddle talks of an entirely different corporeality, an embodied way of being that is 'otherwise at risk'. ${ }^{66}$ In ritual performances, Biddle shows, Warlpiri women bear marks and designs that serve to highlight the size, weight, movement, and, specifically, the fall of the breast. These painted-up breasts repeat an initial ancestral imprinting of country, the Dreaming Ancestors' secretions and remains forming the previously unmarked landscape. Biddle's argument is that the work of Warlpiri women artists invites us to enter into the paintings, becoming 'vulnerable to their sensibilities'. ${ }^{67}$ In asking what these paintings do rather than mean, Biddle invites the dissolution of the boundaries between 'perception', sustained by an ocular engagement, and an affective, sensory experience of the materiality of these works. If such a painting is a 'text', then it is one that is far more than a site for 'content' or an object of discourse.

Looking across this collection, two major insights emerge regarding scholars' engagement with texts, whether they are didactic or 'open' works, canonical or obscure, ostensibly colonial or explicitly resistant. The first is that even those 
texts safely harboured amid a wealth of secondary literature or steeped in colonial mythos remain, at all times, subject to emergent social relations, and therefore each persists as an object within relationality. This is not a simple relativism but rather an attentiveness to sets of relations. Discussing the paintings of renowned Western Desert artist Clifford Possum Tjapaltjarri, Erin Manning states that he explained his works in terms of his relation to country and the networks within and between countries. Having detailed these dynamics, Manning opens a question regarding their textual iterations: what is our own relation to Tjapaltjarri's 'relationscapes' as they grow in fame and travel across international art spaces? The second insight, as such, is that texts are always social and contemporary, and therefore always open to ongoing negotiation. In Katelyn Barney's essay, she returns to Diane Bell's 1983 book Daughters of the Dreaming, received on publication as a progressive challenge to established ideas about Aboriginal women, and then re-read a decade later by Indigenous scholars as fundamentally disempowering. Returning to these critiques, Barney raises a comparison between Bell and white male anthropologists who have reflexively presumed the authority of 'a knowledgeable expert'. Is this researcher-researched relation innately 'Aboriginalist'essentialising Aboriginality as 'other' - and, if so, is this a matter of the text itself or its production? ${ }^{68}$ How might we come to know Bell's text again in the future?

Richard Martin, the author of the most recent contribution republished here, is wary of the kinds of ideologically inflected certainties that some practices of narrating histories bring into being. While acknowledging its analytical importance, he suggests that it is flawed to solely follow an Althusserian logic of interpellation in relation to texts. Support for dominant ideological regimes - however explicit-is never the sole message, nor is it so simply received. Community museums, 'explorer trees' and other admiring commemorations of the settler-colonial project are always open to reappropriation, ambivalence and uncertainties. More specifically, Martin is interested in the ambivalences and contradictions Indigenous people express about living with these localised histories. Working with the literatures 
of anthropology and cultural studies, he issues a challenge to the latter by suggesting that reading 'without diligent ethnography' carries risks of (re)producing 'a politicised interpretation, captive to contemporary forms of radicalism'. ${ }^{69}$ In this, we detect a welcome rapprochement between two disciplines which, despite a shared interest in everyday practice and shared methodologies have, in recent memory, been overly satisfied to deal in caricatures of one another. These caricatures - anthropology as unremittingly colonialist and cultural studies as methodologically shallow-are the product of critiques that are necessary but ultimately limited. We must always read, as Martin suggests, for 'the suggestion of other divergent responses'. ${ }^{70}$

\section{Conclusion}

We see the project of Indigenous cultural studies centring on clarifying and interrogating the production of histories, power and texts. We know, too well, that the relationships between Indigenous and non-Indigenous people within research and academia has been one where, historically, exploitation and unequal power relationships were common; all too often, non-Indigenous academics spoke for Indigenous people. Stuart Hall writes that what is significant in the development of critical intellectual work are the breaks 'where old lines of thought are disrupted, older constellations displaced, and elements, old and new, are regrouped around a different set of premises and themes'. ${ }^{71}$ The convergence of cultural studies and Indigenous studies represents one of Hall's breaks, and this break is filled with possibilities for new ways of engaging with Indigenous knowledges, places and people. The work contained in this collection problematises and disrupts these histories and seeks to create new questions and, from these premises, innovative scholarship. In this convergence, Indigenous academics are returning the gaze that historically was cast upon them and their communities, and non-Indigenous scholars are also striving to build work that reflects the challenges Indigenous people have made to the academic world.

Like the authors collected in this book, we, the editors, hail from differing disciplinary backgrounds, our work intersects 
with Indigenous studies in different ways, we are Indigenous and non-Indigenous people, Australians and recent migrants to Australia. Timothy Neale is a pakeha-or white settler New Zealander - though, like many raised in Aotearoa New Zealand, he has extended family grounded in pakeha, migrant and Maori communities and histories. Having studied settler literature as an undergraduate, he studied cultural studies as a graduate in Melbourne, where his research took him to far north Queensland. He now works in a cultural research centre in Sydney. Eve Vincent is a fifth generation white settler Australian whose country upbringing directed her towards the study of colonial history as an undergraduate in Melbourne, as well as involvement in various Aboriginal rights and environmental campaigns. As a postgraduate student in Sydney she turned to ethnography, and now lectures in an anthropology department. Crystal McKinnon is an Amangu woman from the Yamatji nation, who studied Indigenous history and politics as an undergraduate in Melbourne. Her upbringing around Aboriginal artists and activists has informed her current research, which traces Indigenous histories of resistance in artistic practices. She lectures in Indigenous politics along with working in Aboriginal community organisations in Melbourne.

In collaborating on this book, we found ourselves necessarily staking out our own meeting point, not only creating a new text but also, we hope, (re)performing the gathering of Indigenous and non-Indigenous people engaged at the intersection we are calling 'Indigenous cultural studies'. In collaboration with our authors, we edited many of the pieces collected here, allowing us to include a broad selection of short works within the one volume. We also invited three authors - Tony Birch, Aileen Moreton-Robinson and Crystal McKinnon-to each write a new essay reflecting on a given section, its concerns and the work presented within it. Between them these three essays present thoughts on historical method and the so-called 'history wars', Foucault and apparatuses of power, textuality and category of the 'Aboriginal text', rethinking the grounds that have been - and might yet be - charted by the authors here. The final piece we have included is the product of a literal gathering, a roundtable discussion between the 
book's editors and three former and current editors of the journal-Chris Healy, Stephen Muecke and Katrina Schlunke. In piecing this collection together, and seeking authors and editors to reflect on their contributions, our task was not only to assemble what we saw as some of the best past offerings in this field, but also those which provide inspiration and direction to future scholarship.

In closing, we would like to return to the happy meeting of Gramsci, Hall and the field of Indigenous cultural studies we sketched earlier, as Hall's work also presents certain issues for scholars working at this intersection. On one account, Hall might seem to question the identitarian claims sometimes made in the name of indigeneity, suggesting that the positing of historically consistent subjectivities is always the work of interpellation and construction. Hall acknowledged the power of valorising a past that colonialism has denigrated, though he was clearly more interested in a model of cultural identity formed through the ruptures of the colonial experience: history has intervened, making all of us 'what we have become'. Cultural identity, for Hall, was 'a matter of "becoming" as well as of "being". $7^{2}$ This might present a dilemma to scholars committed to supporting Indigenous aspirations, who may well be deeply invested in essentialist frames of reference. At this juncture recent work by anthropologist James Clifford is particularly insightful, in its use of 'articulation' approaches to argue that 'the whole question of authenticity is secondary'; indigeneity and the 'truth' of difference, he suggests, is only a matter for non-Indigenous scholars in its performances and performativity and not in its being. ${ }^{73}$ By thinking about difference in this way, it is possible to observe that the practices of Indigenous activism may indeed be 'implicated in colonial and neo-colonial (capitalist) structures' of recognition and expropriation while also insisting that they are not ultimately determined by them. Quoting Charles Hale, Clifford suggest that Indigenous politics is best understood as a practice of 'attempting to exercise rights granted by the neoliberal state, while at the same time eluding the constraints and dictates of those very concessions'; an undetermined and open-ended practice of 'becoming' Indigenous whose relation to state hegemony, at any one time, may be radically uncertain. ${ }^{74}$ 


\section{Clifford's chief ethical injunction to students and scholars, therefore, would seem to be to extend an inexhaustible hos- pitality to critical uncertainty. In republishing past offerings we hope to inspire others to take up this invitation to critically reflect on - and engage in - the contingent transactions of Indigenous cultural studies.}

\footnotetext{
Notes

John Hartley, A Short History of Cultural Studies, Sage, London, 2003, p. 2. Graeme Turner, What's Become of Cultural Studies?, Sage, London, 2012, p. 2. Ibid., p. 3.

4 Zane Ma Rhea and Lynette Russell, 'The Invisible Hand of Pedagogy in Australian Indigenous Studies and Indigenous Education', Australian Journal of Indigenous Education, vol. 41, no. 1, 2012, p. 19.

5 See Heidi Norman, 'Mapping More Than Aboriginal Studies: Pedagogy, Professional Practice and Knowledge', Australian Journal of Indigenous Education, vol. 43, no. 1, 2014, p. 43.

6 Rhea and Russell, p. 20.

7 Norman, p. 42.

8 Pat Dudgeon and John Fielder, 'Third Spaces Within Tertiary Places: Indigenous Australian Studies', Journal of Community \& Applied Social Psychology, vol. 16, no. 5, 2006.

9 Linda Tuhiwai Smith, Decolonizing Methodologies: Research and Indigenous Peoples, 2nd ed., Zed Books, London, 2012, p. 4.

10 Audra Simpson and Andrea Smith, Theorizing Native Studies, Duke University Press, Durham, 2014.

11 Lester-Irabinna Rigney, 'Internationalization of an Indigenous Anticolonial Cultural Critique of Research Methodologies: A Guide to Indigenist Research Methodology and its Principles', Wicazo Sa Review, vol. 14, no. 2, 1999, p. 118

12 See Ian Anderson, 'Introduction: The Aboriginal Critique of Colonial Knowing', in Michele Grossman (ed.), Blacklines: Contemporary Critical Writing by Indigenous Australians, Melbourne University Press, Melbourne, 2003, pp. 17-24.

13 Aileen Moreton-Robinson, 'Imagining the Good Indigenous Citizen: Race War and the Pathology of Patriarchal White Sovereignty', in this volume, pp. 310-30.

14 Michel Foucault, 'Two Lectures', in Colin Gordon (ed.), Power/Knowledge: Selected Interviews and Other Writings 1972-1977, Pantheon Books, New York, 1980, pp. 81-1.

15 See Stuart Hall and Tony Jefferson, Resistance through Rituals: Youth Subcultures in Post-War Britain, HarperCollins, London, 1976; Stuart Hall et al., Policing the Crisis: Mugging, the State, and Law and Order, Holmes \& Meier, New York, 1978.

16 Hall, 'On Postmodernism', p. 53.

17 Penny van Toorn, 'Hegemony or Hidden Transcripts? Aboriginal Writings from Lake Condah, 1876-1907', in this volume, pp. 384-407.

18 Van Toorn, pp. 387. See also Ranajit Guha, Dominance without Hegemony: History and Power in Colonial India, Harvard University Press, Cambridge MA, 1997.

19 Van Toorn, pp. 388.

20 Tony Birch, 'The Last Refuge of the "Un-Australian”, in this volume, p. 198.

21 Irene Watson, 'In the Northern Territory Intervention: What Is Saved or Rescued
} 
and at What Cost?', in this volume, pp. 167-86.

22 Tony Birch, 'Footnote to a History War: (archive box no.2)', in Margaret Bradstock (ed.), Antipodes: Poetic Responses, Phoenix Education, Sydney, 2011, p. 1.

23 This account also owes a debt to Althusser's work on the 'lacunar' quality of ideology as the suggested and implied content of governing rules which are, as a whole, logically incoherent. Louis Althusser, 'Ideology and Ideological State Apparatuses', in his Lenin and Philosophy, and Other Essays, New Left Books, London, 1971.

24 Gramsci, Hall reminded us, was born in Sardinia in 1891, a southern island 'which stood in a "colonial" relationship to the Italian mainland'. While the so-called 'southern question' remained of central concern to Gramsci, he did not 'analyse in depth the colonial experience or imperialism, out of which so many characteristically 'racist' experiences and relationships in the modern world have developed'. It was Hall who produced an account of how Gramsci might be used to analyse questions of race and colonialism (see Stuart Hall, 'Gramsci's Relevance for the Study of Race and Ethnicity', Journal of Communication Inquiry, vol. 10, no. 2, 1986, pp. 415-16).

25 Hall, 'Gramsci's Relevance', p. 433.

26 Antonio Gramsci, Selections from the Prison Notebooks of Antonio Gramsci, Lawrence \& Wishart, London, 1971, p. 377.

27 See Aileen Moreton-Robinson (ed.), Sovereign Subjects: Indigenous Sovereignty Matters, Allen \& Unwin, Sydney, 2007; Aileen Moreton-Robinson, 'I Still Call Australia Home: Indigenous Belonging and Place in a White Postcolonizing Society', in Sara Ahmed (ed.), Uprootings/Regroundings, Bloomsbury, London, 2004; Irene Watson, 'Sovereign Spaces, Caring for Country, and the Homeless Position of Aboriginal Peoples', South Atlantic Quarterly, vol. 108, no. 1, 2009. Jane M. Jacobs, Edge of Empire: Postcolonialism and the City, Routledge, London, p. 24.

29 Chris Healy, Forgetting Aborigines, UNSW Press, Sydney, 2008. Some scholars address this problem by making a distinction between the use of the term postcolonial with a hyphen, and postcolonialsm, without a hyphen. Those wishing to stress postcolonialism as a critical, theoretical, disciplinary and political project, rather than a temporal descriptor, use the latter term. This approach is exemplified by Robert Young who argues postcolonialism is best understood as a wide-ranging political project with transformative energies. Its objectives are 'to reconstruct Western knowledge formations, reorient ethical norms, turn the power structures of the world upside down, refashion the world from below'. In the radical inequalities of the globalised present, Young sees colonialism's historical reach, the 'ongoing life' of its 'residues, living remains, lingering legacies' (see Robert Young, 'Postcolonial Remains', New Literary History, vol. 43, no. 1, 2012, pp. 20-1). Stuart Hall proffered that the project of 'postcolonialism' only became possible at a certain time, after the 'high point' of colonial domination has passed. Hall argues: 'So, the postcolonial is not the end of colonisation. It is after a certain kind of colonialism, after a certain moment of high imperialism and colonial occupation - in the wake of it, in the shadow of it, inflected by it - it is what it is because something else has happened before, but it is also something new' (Julie Drew, 'Cultural Composition: Stuart Hall on Ethnicity and the Discursive Turn', in Gary Olson and Lynn Worsham (eds), Race, Rhetoric, and the Postcolonial, State University of New York Press, Albany, 1999, p. 230).

30 Deborah Bird Rose, 'Decolonising the Discourse of Environmental Knowledge in Settler Societies', in this volume, pp.209.

Elizabeth Povinelli, The Cunning of Recognition: Indigenous Alterities and the 
Making of Australian Multiculturalism, Duke University Press, Durham, 2002. and Non-Indigenous Evaluation in a (Post)-Settler Colony', Postcolonial Studies, vol. 15, no. 4, 2012.

\section{Watson, 'In the Northern Territory Intervention', p. 172.}

Ben Dibley, 'Antipodean Aesthetics, Public Policy and the Museum: Te Papa, For Example', in this volume, pp. 271-9o.

Watson, 'In the Northern Territory Intervention'.

Gillian Cowlishaw, 'Performing Aboriginality: The Politics and Poetics of Citizenship in Everyday Life', in this volume, pp. 229-49.

Lisa Slater, "'Calling Our Spirits Home": Indigenous Cultural Festivals and the Making of a Good Life', in this volume, pp. 354-67.

For analyses of pathologisation see Aileen Moreton-Robinson, 'Imagining the Good Indigenous Citizen: Race War and the Pathology of Patriarchal White Sovereignty', in this volume, pp. 310-30; Elizabeth Povinelli, 'The Part That Has No Part' in her Economies of Abandoment, Duke University Press, Durham, NC, 2011, pp. 47-73; Timothy Neale, 'Staircases, Pyramids and Poisons: The Immunitary Paradigm in the Works of Noel Pearson and Peter Sutton', Continuum, vol. 27, no. 2, 2013.

9 Emma Kowal, 'Postcolonial Friction: The Indigenous Governance Machine', in Ghassan Hage and Emma Kowal (eds), Force, Movement, Intensity, Melbourne University Press, Melbourne, 2011.

Watson, 'In the Northern Territory Intervention', p. 167.

Stephen Muecke, 'Experimental History? The "Space” of History in Recent Histories of Kimberley Colonialism', in this volume, pp. 50-63.

S.G. Foster and Bain Attwood, Frontier Conflict: The Australian Experience, National Museum of Australia, Canberra, 2003.

Claude Lévi-Strauss, The Savage Mind, Garden City Press, London, 1966.

Deborah Bird Rose, 'The Saga of Captain Cook: Remembrance and Morality', in Bain Attwood and Fiona Magowan (eds), Telling Stories, Allen \& Unwin, Sydney, 2001, p. 61.

Anne Brewster and Kim Scott, 'Can You Anchor a Shimmering Nation State via Regional Indigenous Roots?', in this volume, pp. 502-22; Kathleen Petyarre and Christine Nicholls, 'Old Lady Mob’ Interview, in this volume, pp. 449-57.

Petyarre and Nicholls, p. 455.

7 Sonia Smallacombe, 'Oral Histories of the Stolen Generation', in this volume, pp. 64-9; Commonwealth Government Human Rights and Equal Opportunity Commission (HREOC), Bringing Them Home: A Report of the National Inquiry into the Separation of Aboriginal and Torres Strait Islander Children from their Families, Human Rights and Equal Opportunity Commission, Sydney, 1997.

For example, see Wendy Lowenstein, Weevils in the Flour: An Oral Record of the 1930s Depression in Australia, Hyland House, Melbourne, 1978.

Michael Jackson, The Politics of Storytelling: Violence, Transgresion and Intersubjectivity, Museum Tusculanum Press, Copenhagen, 2002.

Smallacombe, p. 67.

Rigney, p. 117.

Bronwyn Fredericks, “"There is nothing that identifies me to that place": Indigenous Women's Perceptions of Health Spaces and Places', in this volume, pp. 291-309.

Rigney, pp. 117-18.

4 Rebe Taylor, “'All I Know is History”: Memory and Land Ownership in the Dudley District, Kangaroo Island', 1999 in this volume, pp. 70-90.

Wendy Brady, 'Indigenous Insurgency against the Speaking for Others', in this 
volume, pp. 120.

56 Taylor, p. 31.

57 Alison Ravenscroft, 'The Production of Whiteness: Revisiting Roberta Sykes's Snake Dreaming', in this volume, p. 409.

58 Ibid., p. 416.

59 Goodall, p. 35; David Ritter, 'The Judgement of the World: The Yorta Yorta Case and the "Tide of History", Australian Historical Studies, vol. 35, no. 123, 2004.

60 Eve Vincent, 'Knowing the Country', in this volume, pp. 138-52.

61 Fredericks, p. 294.

62 See, for example, Jennifer Biddle, 'Shame', Australian Feminist Studies, vol. 12, 1997, pp. 227-39.

63 Slater, p. 362.

64 Robyn Ferrell, 'Pinjarra 1970: Shame and the Country Town', in this volume, p. 130.

65 Ibid.

66 Jennifer Biddle, 'Breasts, Bodies, Art: Central Desert Women's Paintings and the Politics of the Aesthetic Encounter', in this volume, p. 426.

67 Ibid., p. 425.

68 See Bain Attwood, 'Introduction: Power, Knowledge and Aborigines', Journal of Australian Studies, no. 35, 1992.

69 Richard J. Martin, "'Reading” the Leichhardt, Landsborough and Gregory Explorer Trees of Northern Australia', in this volume, p. 539.

70 Ibid., p. 540.

71 Stuart Hall, 'Cultural Studies: Two Paradigms', Media, Culture and Society, vol. 2, no. 1,1980, p. 57.

72 Stuart Hall, 'Cultural Identity and Diaspora', in J. Rutherford (ed.), Identity, Community, Cultural Difference, Lawrence \& Wishart, London, 1990, p. 225.

73 James Clifford, Returns: Becoming Indigenous in the Twenty-First Century, Harvard University Press, Harvard, 2013, p. 61.

74 Clifford, pp. 301, 38; Charles Hale, 'Does Multiculturalism Menace? Governance, Cultural Rights and the Politics of Identity in Guatemala', Journal of Latin American Studies, vol. 34, 2002, p. 499. 